\title{
ZOOLOGY
}

DOI https://doi.org/10.30525/978-9934-26-111-4-7

\section{ВИДОВЕ РІЗНОМАНІТТЯ ЗАПОВІДНИХ ТЕРИТОРІЙ ПІВДЕННО-СХІДНОЇ УКРАЇНИ ФАУНИ КОЛЕМБОЛИ (COLLEMВOLA, ENTOGNATHA)}

\author{
Старостенко О. В. \\ кандидат біологічних наук, \\ доцент кафедри біологї \\ Національний медичний університет імені О. О. Богомольияя
}

\author{
Новосад К. В. \\ кандидат біологічних наук, \\ науковий співробітник відділу ботаніки \\ Національний науково-природничий музей \\ Національної академії наук України \\ м. Київ, Україна
}

Колемболи (Collembola, Entognatha) належать до числа найдревніших груп наземних членистоногих. Що широко поширена група мікроартропод, яка характеризується високими показниками чисельності та значним видовим багатством. На сьогоднішній день у світовій фауні налічують близько 6000 видів колембол [1, с. 3]. Колемболи тісно пов'язані з різними типами грунтів і рослинності i заселяють різні горизонти грунтового ярусу. Основним місцем їх розташувння $\epsilon$ скупчення органічного матеріалу на поверхні грунту [3].

Фауна колемболи заповідних територій південно-східної України представлена 16 родинами і 65 родами. Провідними родинами фауни колемболи на заповідних територій Entomobryidae (29 видів, 21,3\% від загального числа видів), Isotomidae (29 видів, 21,3\%) і Onychiuridae (22 види, $16,2 \%$ ), які складають $58,8 \%$ видового складу фауни. Взаємне часткове співвідношення між основними родинами змінюється на досліджуваних заповідних територіях та визначає вигляд фауни кожного заповідника. Багаті видами також родини Neanuridae (12 видів, 8,8\%) і Hypogastruridae (10 видів, 7,4\%). Решта родин представлені окремими видами: Sminthuridae (7 видів, 5,1\%), Katiannidae (6 видів, 4,4\%), Bourletiellidae (6 видів, 4,4\%), Cyphoderidae 
(4 види, 2,9\%) , Sminthurididae (3 види, 2,2\%), Arrhopalitidae (2 види, 1,5\%), Tomoceridae (2 види, 1,5\%). Родини Dicyrtomidae, Neelidae та Oncopoduridae представлені 1 видом та складають по 0,7\% від загальної кількості видів. Слід зазначити, що родини Bourletiellidae і Cyphoderidae складають в основному ксерорезистентні термофільні види, характерні для відкритих місць існування, і є однією з особливостей коллембол степової зони південно-східної України. [4]

Видове багатство і різноманітність степового біотопу виявлено 37 видів колемболи 325 родів і 10 родин. Під час дослідження були відзначені значні коливання кількості видів в серії проб в різні сезони. Мінімальна кількість видів в досліджувальної проби зареєстровано в періоди спаду чисельності влітку: 3 види (Orchesella taurica, Entomobrya multifasciata, Pseudosinlla octopunctata) - в липні і 4 види (Protaphorura serbica, Orchesella taurica, Pseudosinlla octopunctata, Sminthurinus aureus) - в серпні. Найбільше число зареєстрованих видів відзначено в період максимального достатку коллебол в досліджуваному співтоваристві в травні - 20 видів. В цілому зміни чисельності угруповання колемболи i кількості видів корелювали. Можна припустити, що для колемболи, що мешкають в умовах відкритого ландшафту, характерно збільшення видового багатства восени незалежно від гідротермічних умов в біотопі, що лімітують чисельність популяції.

Криві домінування-різноманітності Уіттекера демонструють схожість 3 моделлю «геометричного ряду», що характерно для родин 3 малою кількістю видів, що мешкають в екстремальних екологічних умовах [2].

Таким чином, досліджуваний об'єкт демонстрував значні коливання кількості зареєстрованих видів в різні сезони. Найбільше видове багатство характерно для вологих сезонів з помірними температурами (осінь, зима, весна, початок літа), тоді як в період літньої посухи число фіксованих видів значно знижується. Також, характерна висока агрегованість i низькі показники різноманітності. Найбільша різноманітність і структурованості відзначені для дослідження видів колемболи у вологі сезони (травень, червень, травень, квітень, червень). Найбільш порушена видова структура виявлена в липні серпні, тобто в період з найбільш екстремальних гідротермічних умов. Флюктуруючий тип, що характерний широким розмахом коливань показників видового різноманіття в різні пори року в динаміці (середня чисельність, видове багатство і різноманітність, агрегованість і ін.). Значною часткою рідкісних $\mathrm{i}$ нечисленних видів $\mathrm{i}$ розширеним спектром потенційних домінантів $[4,5]$. 


\title{
Література:
}

1. Гиляров М.С. Коллемболы, их место в системе, особенности и значение. Фауна и экология ногохвосток. Москва: Наука, 1984.С. 3-11.

2. Мэгарран Э. Экологическое разнообразие и его измерение: Пер. с англ. Москва, Мир, 1992. С. 94-95.

3. Определитель коллембол фауны СССР. Под ред. Н.М. Черновой, Б.Р. Стригановой. Москва: Наука, 1988. 214 с.

4. Старостенко О.В. До вивчення сезонної динаміки угруповань коллембол в умовах відкритих ландшафтів степів південно-східної України. Науковий вісник: Сучасна екологія і проблеми сталого розвитку суспільства. Львів: УкрДЛТУ, 1999 б. С. 172-176.

5. Старостенко Е.В. Изучение суточной динамики горизонтальных миграций коллембол (Collembola, Entognatha) по поверхности почвы в условиях открытого ландшафта. Харьков. Т.6, Вип.1. 1998. С. $113-119$.

DOI https://doi.org/10.30525/978-9934-26-111-4-8

\section{ПЕРСПЕКТИВНА РОЛЬ ПЛАСТИКОВИХ ШТУЧНИХ ГНІЗДІВЕЛЬ У ПІДТРИМАННІ ДУПЛОГНІЗНИХ ПТАХІВ НА БЕЗЛЮДІВСЬКИХ ОЧИСНИХ СПОРУДАХ М. ХАРКОВА}

\author{
Ярис О. О. \\ аспірант кафедри зоологіі \\ Харківський національний педагогічний університет \\ імені Г. С. Сковороди \\ Мамедова Ю. П. \\ аспірант кафедри зоології \\ Харківський національний педагогічний університет \\ імені Г. С. Сковороди \\ м. Харків, Україна
}

Орнітофауна території водоочисних споруд м. Харкова представлена 106 видами птахів різних екологічних груп [2, с. 183-186]. Безперечно, протягом усього життєвого циклу, птахи потребують місця для гніздування, ночівлі, живлення тощо. Для успішної зимівлі птахів, вирішальним фактором $є$ не стільки температура повітря, скільки наявність незамерзаючих водойм і ділянок 3 достатньою кормовою базою. Відомо позитивний досвід залучення дуплогніздних птахів, 